\title{
Konjenital Nazolakrimal Kanal Tıkanıklıklarında Yeniden-Problama Nedenlerinin Araştırılması
}

\author{
Investigation of Reasons for Re-probing in Congenital Nasolacrimal Canal Obstructions
}

Selma URFALIOGLU ${ }^{1}$, Gökhan OZDEMIR ${ }^{1}$, Mete GULER ${ }^{1}$, Gamze Gizem DUMAN ${ }^{1}$, Ismail EVGIN ${ }^{1}$, Feyza CALISIR ${ }^{2}$

${ }^{1}$ Kahramanmaras Sutcu Imam University Faculty of Medicine, Department of Ophthalmology, Kahramanmaras, Turkey.
${ }^{2}$ Kahramanmaras Sutcu Imam University Faculty of Medicine, Department of Anesthesiology and Reanimation, Kahramanmaras, Turkey.

Amaç: İlk problamanın başarısız olmasına neden olan ikinci problama uygulamasını gerektiren faktörlerin gösterilmesi amaçlanmıştır.

Gereç ve Yöntemler: Bu Retrospektif vaka serisine, Ocak 2010 ile Aralık 2019 arasındaki Konjenital nazolakrimal kanal tıkanıklığı (KNLKT) tanısı alan ve nazolakrimal kanal (NLK) sondası ile tedavi edilen hastalar dahil edildi. Kahramanmaraş Sütçü İmam Üniversitesi Tıp Fakültesinde bu yıllar arasında KNLKT tanısı alan ve NLK sondası ile tedavi edilen hastaların dosyaları incelendi. Hastaların cinsiyet, yaş, konsültasyon notları, operasyon kayıtları, yeniden probing uygulama sayıları ve sistemik hastalık varlığı gibi özellikleri kaydedildi.

Bulgular: Çalışmaya toplam 110 hasta alındı. Hastaların yaş ortalaması 17,55 5 ,40 (9-34) ay ve 46 kadın (\% 41,8$)$, 64 erkek (\% 58,2) idi. İlk probing sonrası semptomlarda düzelme gösteren 93 hasta (\% 84.5) başarılı kabul edilirken, benzer semptomları olan 17 hastada (\% 15.5$)$ probingin başarısı olduğu kabul edildi. Yaşı 18 aydan küçük veya daha büyük olan hastaların gruplandırılması, araştırma başarısı açısından benzer başarı oranlarına sahipti ( $\mathrm{p}=0,250)$. Cinsiyet $(\mathrm{p}=0,953)$ ve lateralite bakımından başarı oranında fark bulunamadı $(\mathrm{p}=0,116)$. Sekonder sondalama planlanan 14 hastada lokal hastalıklar (burun boşluğu sorunları, kanaliküler daralma, anatomik varyasyon vs.) tespit edildi.

Sonuç: Çalışmamız, cinsiyet, yaş veya lateralitenin araştırmanın başarısı üzerinde hiçbir etkisi olmadığını öne süren diğer çalışmalarla uyumludur. İlk araştırma başarısız olursa, ilk hatanın altında yatan nedenlerin ele alınması ve araştırılmasını da içeren kapsamlı bir yönetim planı, ikinci araştırmadan önce uygulanmalıdır

Anahtar Kelimeler: Nazolakrimal kanal tıkanıklı̆̆ı, Konjenital, Probing

\begin{abstract}
Objective: It was aimed to show the factors leading to failure of first probing, necessitating second probing application.

Material and Methods: In this retrospective case series, patients diagnosed with congenital nasolacrimal duct obstruction (CNLDO) between January 2010 and December 2019 and treated with a nasolacrimal duct (NLD) probe were included. The files of patients diagnosed with CNLDO and treated with NLD probing between these years at Kahramanmaras Sutcu Imam University Medical Faculty Hospital of were reviewed. Patients characteristics including sex, age, consultation notes, operation records, re-probing number and existence of systemic disease were recorded.

Results: A total of 110 patients were recruited into the study finally. The mean age of patients was $17.55 \pm 5.40$ (9-34) months and 46 female (41.8\%), 64 male (58.2\%). While the ninety three patients (84.5\%) showing improvement of symptoms after the first probing considered successful, 17 patients (15.5\%) having smilar symptoms regarded failed probing. Grouping patients with age less than $\leq 18$ months or more had similar success rates with regard to probing success $(p=0.250)$. No difference in success rate was found for gender $(p=0.953)$ and laterality $(p=0.116)$. Local diseases (nasal cavity problems, canalicular narrowing, anatomical variation etc.) were detected in 14 patients, who have been planned for secondary probing.

Conclusion: Our study is in congruity with other studies claiming no effect of sex, age or laterality on probing success. If first probing fails, a thorough management plan including also exploration and handling of reasons underlying the first failure should be implemented before second probing.
\end{abstract}

Keywords: Nasolacrimal duct obstruction, Congenital, Probing

Yazışma Adresi: Selma URFALIOĞLU, Kahramanmaraş Sütçü İmam Üniversitesi Tıp Fakültesi Göz Hastalıkları ABD, Kahramanmaraş, Türkiye, Telefon: +90(344)3003366, Mail: sakyol03@hotmail.com

ORCID No (Sirasıyla): 0000-0002-3709-6988, 0000-0002-0257-9883, 0000-0002-6232-8445, 0000-0001-8690-7436, 0000-0001-9142-2505, 0000-0002$8882-4666$

Geliş tarihi: 20.10 .2020

Kabul tarihi: 25.11 .2020

DOI: $10.17517 /$ ksutfd. 813607 


\section{INTRODUCTION}

Congenital nasolacrimal duct obstruction (CNLDO) has been thought to arise from insufficient canalization of epithelial cells on inferior tip (Hasner valve) of nasolacrimal duct. Patients generally apply with tearing and crusting in newborn or infancy period and examination may reveal epifora, mucopurulent secretion efflux from the punctum on digital pressure, recurrent conjunctivitis and dacryocystitis in advanced cases $(1,2)$.

The course of obstruction may vary and the cases has been reported to open spontaneously above $90 \%$ by the first year (3). The massage over sac region with an aim to increase hydrostatic pressure in order to rupture the membrane in the inferior end may be applied to facilitate spontaneous opening in CNLDO cases (4). When massage the rapy fails, the best option is nasolacrimal duct (NLD) probing, which is an intervention too pen the obstructed end mechanically. When this is not achieved, it may be re-tried or other options such as silicon tube implantation or balon dacryocystoplasty may be applied $(5,6)$.

In this study, we aimed to show the factors leading to failure of first probing, necessitating second probing application.

\section{MATERIAL and METHODS}

The clinical study was performed as a single-center and retrospectively. The files of patients diagnosed with CNLDO and treated with NLD probing between January 2010 and December 2019 at Kahramanmaras Sutcu Imam University Medical Faculty Ophthalmology department were reviewed. All procedures performed in studies involving human participants were in accordone with the institutional and/or national research committee and with the 1964 Helsinki Dedoration and its later amendments or comparable ethical standards. Appraval for the study was granted by the clinical Research Ethics Committee of Kahramanmaras Sutcu Imam University Medical Faculty.

The diagnosis of CNLDO was done based on clinics, history and fluorescein clearance test. For this test, a drop of $2 \%$ fluorescein solution was instilled into the lower conjonctiva fornix of both eyes. The fact hat the paint was cleaned after five minutes was considered as obstruction. The massage treatment were proposed priorly for infants less than nine months of age. Cases whose massage therapy failed with persistent symptoms of recurrent mucopurulent conjunctivitis, underwent probing. As the inclusion criteria in the study; patients characteristics (sex, age at the intervention time), consultation notes, operation records, re-probing number and existence of any systemic disease were recorded. Patients lacking postoperative records with in sufficient follow-up were excluded from the study.

\section{Probing Procedure}

Probing was done under inhalation anesthesia with laryngeal mask. After the operation field is cleaned with bati- cone, a prob, one side is $25 \mathrm{~mm}$ long dilator, the other side is $0,70 \mathrm{mmx} 45 \mathrm{~mm}(22 \mathrm{G})$ prob was used for the procedure. Following upper punctum dilatation, prob was inserted vertically into the punctum, and then horizontally advanced in canaliculus. When reached nasal wall of the sac, prob was retracted slightly and turned into $90^{\circ}$ vertical position and forwarded through nasolacrimal duct until rupture of the membrane felt. After the probing, irrigation with diluted $1 / 3$ methylene blue solution was done and the dye was aspirated with a catheter from inferior meatus, confirming the maintenance of passage. Bilateral probing was applied in bilateral cases in one session. Topical antibiotic and steroid combination therapy was given postoperative one week, four times a day. Follow-up examination comprised of query of tearing and fluorescein clearance test. Disappearance of tearing, no epifora on examination, and a successful fluorescein clearance test with no pooling of dye were accepted success criteria for probing intervention. Inspite of probing, when persistence of obstruction with clinical presentation and history was detected, unsuccessful out come was recorded and the second probing was planned with the same technique.

\section{Statistical analysis}

SPSS (SPSS Inc., Chicago, Ill, USA) statistics program was used for statistical comparisons. The numeric variables were presented mean \pm standard deviation, categorical variables frequency and percentage.

\section{RESULTS}

A total of 110 patients were recruited into the study finally. The mean age of patients was $17.55 \pm 5.40$ (9-34) months and 46 female (41.8\%), 64 male (58.2\%) included into the study. Forty-one patients (37.3\%) had right probing, 41 (37.3\%) had left and 28 (25.5\%) had bilateral nasolacrimal duct probing in the same session. The distribution and general characteristics of patients were demonstrated in (Table 1).

Ninety-three patients $(84.5 \%)$ showing improvement of symptoms after the first probing considered successful, while 17 patients (15.5\%) having similar symptoms regarded failed probing. The mean age was $17.35 \pm 5.46$ months and $18.64 \pm 5.02$ months in successful and failed groups respectively, demonstrating similar meanage features $(p=0.266)$. Grouping patients with age less than $\leq 18$ months or more had similar success rates with regard to probing success ( $\mathrm{p}=0.250$ ), shown in (Table 2 ).

Among 17 failed patients, second probing was implemented in 16 patients, one patient couldn't be operated due to inconvenience of general health status. In second probing group, two patients had Down syndrome, one hydrocephalus, one Down syndrome plus hypothyroidism.

The consultation notes of failed patients were reviewed and seven patients had some medications for some other diseases due to influenza, allergic rhinitis and concha hypertrophy. Following their treatment for the seconditions, 
second probing was applied due to continuing tearing and crusting. In the first probing records during the operation, it was noticed that four patients had canalicular narrowing, two had anatomical variations in nasolacrimal canal, one had cleftlip with meanline defect affecting the lacrimal passage. Other three patients revealed no sign of pathology. Local and systemic diseases distributions of patients scheduled for the second intervention are shown in (Table 3).
Follow up showed that 13 patients among 16 failed patients had less symptoms and findings after second probing. Failure after these cond probing was seen in three patients due to canalicular narrowing in one patient and nasolacrimal canal variation in two patients whose nasolacrimal duct silicon tube intubation was done due to continuation of symptoms.

Table 1. General characteristics of patients with and without secondary probing.

\begin{tabular}{|c|c|c|c|}
\hline & No secondary intervention & Secondary intervention & $\mathbf{p}$ \\
\hline Age (month) & $17,35 \pm 5,46$ & $18.64 \pm 5.02$ & 0.266 \\
\hline $\operatorname{Sex}(F / M)$ & $39 / 54$ & $7 / 10$ & 0.953 \\
\hline Associated systemic disorder & 0 & 4 & $0.001 *$ \\
\hline Associated local disorder & 0 & 14 & $0.001 *$ \\
\hline Right side involvement (R/L) & $38 / 32$ & $3 / 9$ & 0.116 \\
\hline Bilateral cases & 23 & 5 & 0.684 \\
\hline \multicolumn{4}{|c|}{$\begin{array}{l}\text { Mann -whitney } U \text { test, } \\
\text { Chi-square test } \\
{ }^{*} \mathrm{p} \leq 0.05 \text {, The difference between the groups was statistically significant }\end{array}$} \\
\hline
\end{tabular}

Table $2 . \leq 18$ month and $>18$ month patients distributions and percentages.

\begin{tabular}{|l|l|l|l|}
\hline & Successful & Unsuccessful & Total \\
\hline $\begin{array}{l}\mathbf{1 8} \text { month number of } \\
\text { patients (n) (\%) }\end{array}$ & $62(87.3 \%)$ & $9(12.7 \%)$ & $71(100 \%)$ \\
\hline $\begin{array}{l}>\mathbf{1 8} \text { month number of } \\
\text { patients (n) (\%) }\end{array}$ & $31(79.5 \%)$ & $8(20.5 \%)$ & $39(100 \%)$ \\
\hline $\begin{array}{l}\text { Chi-square test } \\
\text { p=0.250 }\end{array}$ & & \\
\hline
\end{tabular}

Table 3. Local and systemic diseases distributions of the second intervention patients.

\begin{tabular}{|l|l|}
\hline Associated systemic disorder & Number (n) \\
\hline Down syndrome & 2 \\
\hline Hydrocephalus & 1 \\
\hline $\begin{array}{l}\text { Down syndrome + hypothyroidism } \\
\text { Associated local disorder }\end{array}$ & 1 \\
\hline $\begin{array}{l}\text { Nasal passage problems (influenza, allergic rhinitis and } \\
\text { concha hypertrophy) }\end{array}$ & 7 \\
\hline $\begin{array}{l}\text { Anatomical variations in nasolacrimal canal } \\
\text { Canalicular narrowing }\end{array}$ & 2 \\
\hline Cleftlip with meanline defect & 4 \\
\hline
\end{tabular}




\section{DISCUSSION}

In the treatment of congenital nasolacrimal duct obstruction, a follow up approach according to the age and history of sypmptoms has been accepted widely due to high success rate of conservative management (2). While massage therapy is effective for newborns and later ages, the most accepted minimally invasive procedure after the one year is probing $(2,5)$. Literature shows many researches investigating the relationship between probing and age. Studies suggest that conservative therapy should be chosen firstly before one year of age, while probing may be considered for later ages $(1,5)$. Rahim et al. in their study evaluating probing success under 1 year of age and above 1 year old, they found success rates of $85 \%$ and $72.5 \%$, respectively (7). Similarly, since the success decreases with age, it has been argued that probing is most appropriate for children under 3 years of age $(8,9)$. Increased age may lead to complex obstruction through augmenting the fibrous component of nasolacrimal duct (9-11). However, studies arguing that age, laterality and sex don't have an effect on probing successal so exist $(12,13)$. Our study had a success rate for probing of $87.3 \%$ in patients less 18 months of age compared to $79.5 \%$ in patients older than 18 months, both of which had similar success rates. Our study is in congruity with other studies claiming no effect of sex, age or laterality on probing success.

When the complaints continues in spite of first probing, a second probing may be tried (14). Re-probing has no standard intervention time and depends on the re-start of the complaints. Many researches indicated an association between age and probing success but it appears that age is not the only risk factor and other factors should also be sought for failed outcomes (15). Our study revealed that the involvement of nasal passage was the commonest reason leading to re-probing. This implies that patients undergoing second probing should be evaluated in ear-nose-throat clinics before reoperation. Causes leading to nasal mucosal edema and congestion such as allergic rhinitis, influenza infection, and concha hypertrophy should be detected and treated before hand to prevent interventional procedures for CNLDO.

Failed probing was related to canalicular narrowing and lacrimal passage variations in our study. When noticed canalicular narrowing during probing, attention should be given to prevent canalicular damage and/or creating false passages (16). In three of four patients whose canalicular narrowing was detected, although second probing was succesful too pen the passage, silicon tube intubation was required in one patient due to recurrence of the symptoms. Anatomical variations of nasolacrimal passage may not be noticed at the examination. In two patients whose we faced the failure of second probing in the operation room, we decided silicone tube intubation under endoscopy, which showed that nasolacrimal duct opening was located in the middle meatus instead of inferior meatus.
The anesthesia method may differ during CNLDO. It may be introduced in office settings under sedation or general inhalation anesthesia is another common option $(17,18)$. We gave general inhalation anesthesia in operation room to all patients, so we didn't observe any complications (punctum laceration, canalicular damage etc.) arising from pain and sudden movements during the procedure.

Limitatios of our study include a relative low number of cases that we culled out patient files from our hospital archive.

In conclusion, Congenital nasolacrimal duct obstruction management requires a planning taking into consideration patient's age and history. If conservative therapy fails, probing is an effective and safe procedure. When first probing fails, a second one may be tried but before that a management plan exploring and handling the reasons underlying the first failure should be implemented.

Conflict of Interest and Financial Status: Our study has not been financed by an institution and institution. In this study, there is no conflict of interest among the authors on any subject.

Research Contribution Rate Statement Summary: The authors declare that, they have contributed equally to the manuscript.

\section{REFERENCES}

1. Olitsky SE. Update on congenital nasolacrimal duct obstruction. Int Ophthalmol Clin. 2014;54(3):1-7.

2. Takahashi Y, Kakizaki H, Chan WO, Selva D. Management of congenital nasolacrimal duct obstruction. Acta Ophthalmol. 2010;88(5):506-13.

3. Avram E. Insights in the treatment of congenital nasolacrimal duct obstruction. Rom J Ophthalmol. 2017;61(2):101-6.

4. Karti O, Karahan E, Acan D, Kusbeci T. The natural process of congenital nasolacrimal duct obstruction and effect of lacrimal sac massage. Int Ophthalmol. 2016;36(6):845-9.

5. Vagge A, FerroDesideri L, Nucci P, Serafino M, Giannaccare G, Lembo A, et al. Congenital Nasolacrimal Duct Obstruction (CNLDO): A Review. Diseases. 2018;6(4):96.

6. Tai ELM, Kueh YC, Abdullah B. The Use of Stents in Children with Nasolacrimal Duct Obstruction Requiring Surgical Intervention: A Systematic Review. Int J Environ Res Public Health. 2020;17(3):1067.

7. Rahim S, Nanda R, Gupta D. Result of Probing for Congenital Nasolacrimal Duct Obstruction in Children Less than 1 Year Versus Children Greater than 1 Year. JK Science. 2019;21(4):1569.

8. Perveen S, Sufi AR, Rashid S, Khan A. Success rate of probing for congenital nasolacrimal duct obstruction at variousages. J Ophthalmic Vis Res. 2014;9(1):60-9.

9. Rajabi MT, Abrishami Y, Hosseini SS, Tabatabaee SZ, Rajabi MB, Hurwitz JJ. Success rate of late primary probing in congenital nasolacrimal duct obstruction. J Pediatr Ophthalmol Strabismus. 2014;51(6):360-2.

10. Yilmaz T, Yılmaz A, Kırgız A, Taskapılı M. The efficacy and safety of probing as a treatment procedure for congenital nasolacrimal duct obstruction. Istanbul Med J. 2013;14(3):191-4. 
11. Ali MJ, Kamal S, Gupta A, Ali MH, Naik MN. Simple vs complex congenital nasolacrimal duct obstructions: etiology, management and outcomes. Int Forum Allergy Rhinol. 2015;5(2):174-7.

12. Une VL, Kulkarni SS, Nandedkar VS. Effect of Probing in Congenital Nasolacrimal Duct Obstruction in Children Older Than 2 Years. J Pediatr Ophthalmol Strabismus. 2019;56(3):141-5.

13. Valcheva KP, Murgova SV, Krivoshiiska EK. Success Rate of Probing for Congenital Nasolacrimal Duct Obstruction in Children. Folia Med (Plovdiv). 2019;61(1):97-103.

14. Napier ML, Armstrong DJ, McLoone SF, McLoone EM. Congenital Nasolacrimal Duct Obstruction: Comparison of Two Different Treatment Algorithms. J Pediatr Ophthalmol Strabismus. 2016;53(5):285-91.

15. Beato J, Mota, Á, Gonçalves, N, Santos-Silva R, Magalhaes A, Breda J, et al. Factors Predictive of Success in Probing for Congenital Nasolacrimal Duct Obstruction. J Pediatr Ophthalmol Strabismus. 2017;54(2):123-7.

16. Petris C, Liu D. Probing for congenital nasolacrimal duct obstruction. Cochrane Database Syst Rev. 2017;7(7):CD011109.

17. Hung CH, Chen YC, Lin SL, Chen WL. Nasolacrimal Duct Probing under Topical Anesthesia for Congenital Nasolacrimal Duct Obstruction in Taiwan. Pediatr Neonatol. 2015;56(6):4027.

18. Xiang Q, Gao X, Chen X, Qi J, Fang J. Nasolacrimal Duct Probing for Young Children With Congenital Nasolacrimal Duct Obstructions in China: A 10-Year Systematic Review. J Pediatr Ophthalmol Strabismus. 2019;56(6):365-72. 